\title{
BEX3 wt Allele
}

National Cancer Institute

\section{Source}

National Cancer Institute. BEX3 wt Allele. NCI Thesaurus. Code C52900.

Human BEX3 wild type allele is located in the vicinity of Xq22.2 and is approximately $2 \mathrm{~kb}$ in length. This allele, which encodes protein BEX3, is involved in the regulation of nerve growth factor-mediated apoptosis. 